\title{
ANALISIS KEBUTUHAN KARAKTER MAHASISWA PSIKOLOGI FAKULTAS ILMU SOSIAL DAN HUMANIORA UIN SUNAN KALIJAGA YOGYAKARTA
}

\author{
Sara Palila \\ Program Studi Psikologi Fakultas Ilmu Sosial dan Humaniora \\ UIN Sunan Kalijaga \\ J1 Marsda Adisucipto Yogyakarta \\ sarahanafie@gmail.com
}

\begin{abstract}
This study aims to find the characteristics that are needed by undergraduate students in Psycholocology under the Faculty of Social Sciences and Humanities Univeritas Islam Negri (UIN) Sunan Kalijaga Yogyakarta. Qualitative approach was used in this study. Data were obtained through interviews and FGD (Focused Group Discussion) with 38 students, five lecturers in which two of them are administrators of study program. The data was analyzed through some steps, which are data organization, data reduction on unit analysis, coding and interpretation. The results showed that three principal characters are needed by students: persistence, self-regulation, and empathy. These principal character appears in many forms derived characters. Characters derived from the persistence of the most widely appeared among others are disciplined, proactive, responsibility, consistent, and enthusiasm / passion. Characters derived from self-regulation appears most among others are optimistic, confident, tough, resilient, and positive thinking. While the derivative character of empathy most emerging among others are working together, to appreciate and respect others, listen and understand others.
\end{abstract}

Key Words : emphaty, persistence, students' characteristic, self regulation

\begin{abstract}
Abstrak
Penelitian ini bertujuan untuk menemukan rumusan karakter-karakter yang dibutuhkan oleh mahasiswa Program Studi Psikologi Fakultas Ilmu Sosial dan Humaniora UIN Sunan Kalijaga Yogyakarta. Data penelitian diperoleh melalui wawancara dan FGD (Focused Group Discussion) terhadap informan yang terdiri dari 38 mahasiswa, lima orang dosen, dua di antaranya sebagai pengurus prodi Psikologi Fishum Universitas Islam Negri (UIN) Sunan Kalijaga Yogyakarta. Data yang diperoleh dalam penelitian ini dianalisis melalui beberapa tahap yaitu organisasi data, reduksi data ke dalam satuan-satuan analisis, koding, pengujian terhadap dugaan, dan interpretasi. Hasil penelitian menunjukkan bahwa ada tiga karakter pokok yang dibutuhkan oleh mahasiswa Program Studi Psikologi Fishum UIN Sunan Kalijaga Yogyakarta, yaitu kegigihan, regulasi diri, dan empati. Ketiga karakter pokok tersebut muncul dalam berbagai bentuk karakter turunan. Karakter turunan dari kegigihan
\end{abstract}


yang paling banyak muncul antara lain adalah disiplin, proaktif, tanggung jawab, konsisten, dan antusias/semangat. Karakter turunan dari regulasi diri yang paling banyak muncul antara lain adalah optimis, percaya diri, tangguh, tabah, dan berpikir positif. Sedangkan karakter turunan dari empati yang paling banyak muncul antara lain adalah kerja sama, menghargai dan menghormati orang lain, mendengarkan dan memahami orang lain.

Kata kunci: empati, karakteristik mahasiswa, kegigihan, regulasi diri

\section{Pendahuluan}

Lexmond dan Reeves (2009) menjelaskan bahwa menjadi 'karakter yang baik' berarti unggul dalam tugas mengejar kehidupan yang baik. Menurut pengertian tersebut, karakter lebih merepresentasikan sekumpulan keterampilan hidup daripada disposisi moral. Karakter sebagai kemampuan personal yang dihubungkan dengan hasil berupa kehidupan yang baik.

Kementerian Pendidikan Nasional (2010) mendefinisikan karakter sebagai "bawaan, hati, jiwa, kepribadian, budi pekerti, perilaku, personalitas, sifat, tabiat, temperamen, watak". Berkarakter adalah berkepribadian, berperilaku, bersifat, bertabiat, dan berwatak". Karakter mulia berarti individu memiliki pengetahuan tentang potensi dirinya, yang ditandai dengan nilai-nilai seperti reflektif, percaya diri, rasional, logis, kritis, analitis, kreatif dan inovatif, mandiri, hidup sehat, bertanggung jawab, cinta ilmu, sabar, berhati-hati, rela berkorban, pemberani, dapat dipercaya, jujur, menepati janji, adil, rendah hati, malu berbuat salah, pemaaf, berhati lembut, setia, bekerja keras, tekun, ulet/gigih, teliti, berinisiatif, berpikir positif, disiplin, antisipatif, inisiatif, visioner, bersahaja, bersemangat, dinamis, hemat/efisien, menghargai waktu, pengabdian/dedikatif, pengendalian diri, produktif, ramah, cinta keindahan (estetis), sportif, tabah, terbuka, dan tertib. Individu juga memiliki kesadaran untuk berbuat yang terbaik atau unggul, dan individu juga mampu bertindak sesuai potensi dan kesadarannya tersebut. Karakteristik adalah realisasi perkembangan positif sebagai individu (intelektual, emosional, sosial, etika, dan perilaku).

Karakter dibutuhkan untuk membuat seseorang dapat mengejar dan mencapai kesejahteraan individual mereka sendiri. Kehidupan yang baik dapat dihubungkan dengan kebahagiaan atau kesejahteraan subjektif. Pengertian tentang kehidupan yang baik juga berkembang dari waktu ke waktu. Konsep yang berkembang pada abad ke-20 menggambarkan 'karakter yang baik' sebagai pengorbanan-diri dan individu yang altruistik, namun hal itu bukan konseptualisasi yang sempurna. Kehidupan yang baik adalah kehidupan yang baik bagi diri sendiri juga (Lexmond dan Reeves, 2009).

Pembentukan karakter dimulai sejak masa kecil. Karakter individu tumbuh dari waktu ke waktu melalui proses menyuling pemahaman, bergumul dengan perasaan yang sering berkonflik, dan perbaikan keterampilan dalam berperilaku (Beland, 2003). Manusia mengembangkan moral dan karakter dalam konteks sosial dalam komunitas atau masyarakat mereka (Kohlberg, 1984). Komunitas tersebut mencakup keluarga, teman sebaya, kelas, sekolah, tetangga, dan di luar itu semua (Vezzuto, 2004). Keluarga merupakan sistem dasar dimana individu mengembangkan 
moral dan atribut karakter mereka. Sedangkan komunitas sekolah menyediakan kondisi lain untuk membangun kompetensi emosional dan sosial mereka. Sekolah merupakan salah satu bentuk dari institusi pendidikan.

Institusi pendidikan merupakan salah satu tempat yang dapat dijadikan sebagai wahana pembentukan karakter karena merupakan wadah yang bersifat terstruktur, sistematis, berjenjang, dan berkelanjutan. Vezzuto (2004) mengemukakan bahwa melalui sekolah dan komunitas kelas, pengembangan karakter dapat dipelihara dengan menyediakan kesempatan kepada siswa untuk mendiskusikan isu, mengembangkan aturan dan norma, pemecahan masalah, berbagi cara pandang, mempraktekkan perilaku prososial, dan rencana kegiatan. Penyediaan kesempatan kepada siswa untuk sukarela terlibat dalam proyek pelayanan masyarakat juga dapat menyediakan dimensi lain dalam konteks komunitas. Semua hal tersebut membuat proses pembentukan karakter menjadi lebih efektif dan efisien.

Dunia pendidikan memiliki tanggung jawab besar terhadap perkembangan generasi muda. Waluyo (2011) mengemukakan bahwa tenaga pendidik memiliki peranan yang cukup besar dalam membentuk karakter anak didiknya. Kepala sekolah, guru, pimpinan perguruan tinggi, dan dosen harus memberikan perhatian serta pendampingan lebih besar kepada peserta didik dalam membentuk pola pikir dan perilakunya.

Pengarus utamaan pendidikan karakter sudah banyak diwacanakan baik pada tataran konsep maupun kebijakan. Semua pihak setuju bahwa kepentingan terhadap implementasi pendidikan karakter sudah sangat mendesak. Baru-baru ini Menteri Pendidikan Nasional (Mendiknas)
Mohammad Nuh dalam pidato sambutannya pada upacara Hari Pendidikan Nasional 2 Mei 2011 di Kementerian Pendidikan Nasional menegaskan pentingnya pendidikan berbasis karakter dengan segala dimensi dan variasinya. Mendiknas juga menyatakan bahwa mulai tahun ajaran 2011/2012 mendatang pemerintah berencana menerapkan pendidikan karakter yang materinya akan diberikan mulai dari jenjang pendidikan usia dini (PAUD) sampai perguruan tinggi (Kedaulatan Rakyat, 3 Mei 2011). Semangat gerakan pendidikan karakter juga tampak pada tema besar Hari Pendidikan Nasional 2 Mei 2011 yaitu: "Pendidikan Karakter sebagai Pilar Kebangkitan Bangsa" dengan sub tema "Raih Prestasi Junjung Tinggi Budi Pekerti".

Tahap pembentukan karakter yang cukup krusial adalah tahap remaja awal hingga akhir. Beberapa penelitian menunjukkan bahwa pembentukan karakter lebih mudah dilakukan pada usia remaja. Salah satunya adalah penelitian yang dilakukan oleh Nelson, dkk (2005) yang menemukan bahwa perubahan hormonal selama masa remaja membuat masa tersebut sebagai saat yang fleksibel untuk menetapkan atau mendirikan kembali pola perilaku. Hal tersebut menunjukkan bahwa remaja lebih mudah untuk berubah daripada orang dewasa.

Dalam konteks institusi pendidikan, individu pada usia remaja, khususnya remaja akhir, pada umumnya tengah berada dalam lingkungan pendidikan perguruan tinggi. Individu tersebut disebut dengan mahasiswa. Karakter mahasiswa yang berada pada tahap transisi antara remaja menuju dewasa ini masih memberikan peluang untuk dapat dibentuk. Oleh karena itu, institusi perguruan tinggi diharapkan mampu memberi muatan pembentukan karakter di dalam kurikulum yang diberikan kepada mahasiswa. Karakter 
tidak hanya akan berguna bagi kehidupan mahasiswa secara umum namun secara khusus juga berpengaruh terhadap prestasi mahasiswa (Veenstra \& Kupyer, 2002).

Dari pemaparan tersebut, dapat dilihat bahwa perguruan tinggi memiliki tugas lain di luar pendidikan akademik. Tugas tersebut adalah merancang kurikulum yang berbasis pendidikan karakter. Pengarusutamaan pendidikan karakter dapat dilakukan melalui kegiatan-kegiatan di kelas, pemberian contoh-contoh dalam penjelasan materi, serta tugas-tugas di lapangan.

Kegelisahan mengenai mendesaknya implementasi pendidikan karakter semakin terasa salah satunya adalah karena adanya perilaku golongan terpelajar yang mencakup siswa, mahasiswa, bahkan para sarjana yang menunjukkan tidak berkembangnya karakter positif di dalam setiap diri individu tersebut. Beberapa contoh fenomena yang menunjukkan perilaku tersebut antara lain banyaknya tawuran antar siswa yang dipicu oleh permasalahan yang sepele, perilaku para siswa maupun mahasiswa yang masih menghalalkan segala cara untuk mendapat nilai yang bagus seperti mencontek, mencari bocoran soal, dan sebagainya. Contoh lain adalah ketika banyak para sarjana yang mangambil jalan pintas ketika hendak mendapatkan pekerjaan, seperti memanfaatkan "orang dalam" untuk memuluskan jalan, atau berusaha mempelajari psikotes agar dapat lolos meskipun kompetensi maupun kepribadiannya tidak memadai untuk pekerjaan tersebut.

Semakin banyaknya fenomena seperti yang telah dijelaskan di atas, dapat ditarik kesimpulan bahwa banyak karakter positif dalam diri generasi muda yang luput untuk dikembangkan dalam proses pendidikan yang telah mereka lalui. Beberapa karakter positif tersebut antara lain jujur, disiplin, daya juang, bertanggungjawab, empati dan lain sebagainya. Hal tersebut menunjukkan bahwa pembentukan karakter dalam sistem pendidikan di Indonesia belum mendapat porsi yang cukup. Kondisi seperti ini yang melahirkan kaum muda yang hanya cerdas secara kognitif namun tidak secara mental dan spiritual. Oleh karena itu, institusi pendidikan di negeri ini semakin didesak untuk melakukan refleksi atas konsep dan praktik yang selama ini telah diimplementasikan.

Sumargono (2011) mengkritisi kurikulum pendidikan di Indonesia yang tidak proporsional sebagai penyebab saat ini mahasiswa kurang memiliki karakter yang kuat. Peserta didik terlalu dijejali dengan materi-materi ilmu pengetahuan dan teknologi yang berasal dari luar negeri sedangkan materi yang berkaitan dengan budi pekerti, kerohanian, serta muatan lokal diberi porsi yang sangat sedikit. Minimnya porsi pendidikan karakter dianggap sebagai penyebab munculnya perilaku siswa maupun mahasiswa yang tidak sesuai dengan harapan seperti sikap-sikap rendahnya daya juang, kejujuran, tanggung jawab, empati, dan karakter positif lainnya.

Ketidak seimbangan ini juga dirasakan oleh para staf pengajar di Fakultas Ilmu Sosial dan Humaniora Universitas Islam Negeri Sunan Kalijaga Yogyakarta, khususnya di dalam Program Studi (prodi) Psikologi. Aktivitas pembelajaran saat ini masih terfokus pada aspek keilmuan dan belum secara khusus menyentuh aspek pembentukan karakter. Implementasi muatan karakter masih dilakukan secara sporadis, tidak sistematis, dan hanya oleh beberapa dosen saja. Hal ini menunjukkan bahwa pada dasarnya kebutuhan muatan karakter telah dirasakan meskipun hanya oleh segelintir dosen saja. Implementasi muatan karakter dalam satuan perkuliahan 
tentu akan lebih maksimal apabila dilakukan secara sistematis yaitu terencana, terukur, dan terevaluasi secara berkala.

Kegelisahan mengenai mendesaknya implementasi pendidikan karakter ini kemudian tertuang dalam diskusi dosen pada tanggal 25 Januari 2011 yang dilatarbelakangi beberapa sikap mahasiswa baik di kelas maupun di luar kelas yang dirasa kurang sesuai dengan norma umum sebagai mahasiswa. Sikap mahasiswa tersebut tampak mulai dari reaksinya di dalam kelas diantaranya keluhan keberatan terhadap beban tugas kuliah, cenderung tidak memperhatikan teman lain yang sedang presentasi, kerja kelompok yang kurang harmonis, hingga pada kasus khusus seperti komentar yang kurang pantas mengenai kondisi fisik dosen pengajar pada lembar Indeks Kinerja Dosen (IKD). Penanaman karakter saat ini seharusnya tidak lagi terbatas pada wacana namun harus segera diimplementasikan hingga satuan terkecil aktivitas perkuliahan. Konsep karakter yang diimplementasikan hingga satuan aktivitas perkuliahan akan memudahkan para dosen mengusung pendidikan karakter ini secara bersama-sama.

Karakter empati misalnya, setelah dirumuskan bahwa karakter tersebut diperlukan oleh mahasiswa, maka seluruh dosen dapat mengaplikasikannya dalam setiap aktivitas pembelajaran mata kuliahnya. Empati dapat terus ditanamkan misalnya berupa sikap mahasiswa di kelas yang memperhatikan kelompok yang sedang presentasi di depan kelas dengan minat dan keseriusan. Pentingnya muatan karakter pada Prodi Psikologi sesungguhnya telah tertuang dalam Visi Prodi sebagai berikut : "Menjadi Prodi Psikologi yang terdepan dalam melahirkan teori-teori psikologi yang bersumber dari Islam dan mengintegrasikannya dengan pandangan
Psikologi modern serta menggunakannya untuk meningkatkan kualitas sumber daya manusia menjadi insan yang beriman, bertaqwa, berakhlak mulia, dan memiliki rasa tanggung jawab kemasyarakatan".

Muatan karakter juga dijabarkan dalam misi prodi yaitu: (1) Membentuk perspektif psikologi yang bersumber dari ajaran Islam, (2) Menghasilkan lulusan Sarjana Psikologi yang memiliki kompetensi tinggi dalam bidang Psikologi yang bersumber dari ajaran Islam dan memiliki iman dan taqwa yang kuat serta akhlak yang mulia, (3) Mengembangkan penelitian di bidang Psikologi yang bersumber dari ajaran Islam, (4) Menyediakan pelayanan masyarakat di bidang Psikologi yang berwawasan Islam.

Visi dan misi tersebut secara nyata menunjukkan bahwa pembentukan karakter menjadi salah satu tujuan prodi Psikologi. Meskipun demikian, hingga saat ini prodi Psikologi masih belum menemukan rumusan karakter yang harus dibangun dalam diri peserta didiknya. Kondisi ini telah menjadi kegelisahan para dosen sejak lama. Kegelisahan ini juga muncul karena ilmu Psikologi khususnya tidak hanya terbatas pada aspek kognitif namun juga mencakup pada aspek afektif dan perilaku. Selain kompetensi keilmuan yang harus dikuasai, seorang mahasiswa Psikologi juga diharapkan memiliki karakter yang dapat mendukung sejak dalam proses pembelajaran hingga dalam proses aplikasi keilmuan setelah mereka lulus dan terjun ke masyarakat. Idealnya bekal pendidikan karakter ini sudah mereka dapatkan sejak hari pertama mahasiswa menginjakkan kakinya di perguruan tinggi.

Karakter yang perlu dikembangkan sangat unik dan bersifat individual tergantung pada situasi dan kondisi yang dihadapi seseorang, misalnya pada pendidikan tingkat universitas seperti prodi 
Psikologi UIN Sunan Kalijaga. Situasi dan kondisi pada masing-masing universitas tentu berbeda antara satu dengan yang lain, sehingga karakter yang dikembangkan juga akan berbeda tergantung kebutuhan yang disesuaikan dengan tantangan yang dihadapi masing-masing meskipun bertujuan sama yaitu mengusung pengembangan karakter, oleh karena itu tahap yang perlu diperhatikan sebelum perancangan kurikulum berbasis pendidikan karakter adalah analisis kebutuhan. Pada tahap ini, pembuat kebijakan harus memetakan karakter apa saja yang dibutuhkan oleh mahasiswa. Salah satu cara yang dapat digunakan untuk memetakan kebutuhan tersebut adalah menggali informasi dari mereka yang terlibat dalam proses perkuliahan. Tahap selanjutnya adalah memasukkan rumusan hasil pemetaan karakter tersebut ke dalam kurikulum pendidikan. Kurikulum ini yang nantinya digunakan sebagai dasar penyusunan satuan acara perkuliahan dan mengejawantah dalam proses perkuliahan. Penelitian ini memfokuskan pada tujuan perumusan karakter yang akan digunakan sebagai dasar implementasi muatan karakter khususnya dalam satuan acara perkuliahan.

\section{Metode Penelitian}

Informan dalam penelitian ini terbagi menjadi tiga kelompok, yaitu pengelola program studi, dosen, dan mahasiswa pada Program Studi Psikologi Fakultas Ilmu Sosial dan Humaniora UIN Sunan Kalijaga Yogyakarta. Informan dari kelompok pengelola program studi diwakili oleh dua orang, yaitu satu orang pengelola aktif dan satu orang lagi mantan pengelola program studi. Kedua informan dipilih untuk membandingkan proses pengelolaan mahasiswa dari generasi yang berbeda. Informan dari kelompok dosen pada awalnya direncanakan terdiri dari seluruh dosen yang ada di program studi karena jumlahnya yang cukup sedikit. Namun dosen yang bersedia hadir dalam proses pengambilan data hanya berjumlah tiga orang dari 13 orang yang direncanakan hadir. Tiga orang dosen tersebut sudah cukup mewakili setiap angkatan, dalam arti dosen-dosen tersebut pernah mengajar setiap angkatan yang ada di program studi Psikologi dari angkatan pertama sampai angkatan yang paling baru. Proses pemilihan informan dari kelompok mahasiswa mempertimbangkan keterwakilan dari setiap angkatan. Pada awalnya, direncanakan setiap angkatan mahasiswa, yaitu angkatan 2005 sampai dengan 2010 terwakili dalam penelitian ini, namun karena adanya hambatan teknis, informan yang ada hanya perwakilan dari angkatan 2005, 2007, 2008, dan 2009 berjumlah 30 orang.

Data penelitian ini dikumpulkan melalui teknik wawancara individual dan diskusi kelompok terarah. Wawancara individual dilakukan terhadap informan pengelola prodi, sedangkan diskusi kelompok terarah dilakukan terhadap informan dosen dan mahasiswa. Diskusi kelompok terarah (FGD) dilakukan dengan panduan atau pedoman umum, mencantumkan isu-isu yang ingin diketahui tanpa menentukan secara kaku urutan pertanyaannya. Seluruh proses diskusi kelompok terarah dengan informan didokumentasikan dengan recorder.

Pertanyaan turunan dari pertanyaan penelitian yang diajukan kepada setiap kelompok dibedakan sesuai dengan tujuan. Hal ini dilakukan dengan pertimbangan bahwa hal yang dialami oleh setiap kelompok berbeda, sehingga hal yang dapat diungkap dari setiap kelompok juga berbeda.

Pertanyaan-pertanyaan yang diajukan kepada kelompok pengelola program studi 
lebih difokuskan pada visi dan misi prodi, baik dalam proses penyusunan maupun dalam proses internalisasi visi misi tersebut pada setiap staf pengajar di prodi tersebut. Selain itu juga diajukan pertanyaan tentang karakter yang dibutuhkan oleh mahasiswa maupun lulusan prodi Psikologi, seberapa penting karakter tersebut, serta muatan pengembangan karakter tersebut dalam visi misi prodi. Pertanyaan-pertanyaan yang diajukan kepada kelompok dosen lebih diwarnai oleh pemahaman informan tentang keilmuan Psikologi, visi misi program studi, serta kaitan kedua hal tersebut dengan usaha mengusung pengembangan karakter. Selain menggali karakter-karakter yang dibutuhkan oleh mahasiswa dan lulusan program studi Psikologi serta seberapa penting pengembangan karakter tersebut untuk dilakukan, pertanyaan tentang implementasi pengembangan karakter yang sudah dilakukan selama ini dalam proses pembelajaran sekaligus kontrol terhadap implementasi tersebut juga ditanyakan. Berbeda dengan dua kelompok informan sebelumnya, pertanyaan-pertanyaan yang diajukan kepada kelompok informan mahasiswa lebih difokuskan pada pengalaman selama menjalani perkuliahan di prodi Psikologi, serta karakter-karakter yang dibutuhkan agar sukses menjalaninya. Selain itu juga ditanyakan tentang karakter yang dibutuhkan untuk survive di dunia kerja bagi para mahasiswa yang sudah memiliki pengalaman bekerja sesuai bidangnya, yaitu Psikologi, serta perbedaannya dengan karakter yang pertama.

Dokumen data dalam penelitian ini berupa narasi, deskripsi, dokumen tertulis, dan dokumen rekaman suara dilakukan proses pengolahan dengan teknik koding, analisis, dan interpretasi (Poerwandari, 1998). Proses pengolahan data dilakukan melalui beberapa tahapan, yaitu organisasi data, reduksi data dalam satuan-satuan analisis, koding, pengujian terhadap dugaan, dan interpretasi. Prosedur analisis data dilakukan dengan mendengarkan rekaman untuk mengenal data asli, mentranskripsi rekaman menjadi verbatim, melakukan koding terhadap verbatim, menganalisis hasil koding, dan membuat interpretasi.

\section{Hasil dan Pembahasan}

Jawaban dari pertanyaan penelitian yaitu karakter-karakter yang dibutuhkan oleh mahasiswa prodi Psikologi yang muncul pada masing-masing kelompok bercorak sama. Temuan dari masing-masing kelompok dapat digambarkan sebagai berikut :

a. Kelompok pengelola program studi

Secara umum, menurut informan, karakter yang dianggap perlu dimiliki oleh mahasiswaPsikologiadalahkarakter-karakter yang berhubungan dengan kemampuan untuk mengatur diri sendiri dalam bentuk mengarahkan perhatian dan usaha untuk mencapai tujuan. Beberapa karakter yang berhubungan dengan kemampuan tersebut yang dimunculkan dari kelompok ini adalah disiplin, tanggung jawab, konsekuen, concern, totalitas, komitmen, profesional, dan proaktif. Selain itu juga ada karakter jujur yang juga dianggap perlu karena dapat individu melakukan koping yang efektif terhadap permasalahan yang dihadapi. Informan juga mengungkap karakterkarakter lain yang perlu dimiliki berupa kemampuan untuk berhubungan dengan orang lain secara efektif. Sebagai contoh, karakter yang muncul adalah kemampuan untuk mendengarkan dan menghargai orang lain, respek atau menghormati, bekerjasama, memahami dan tidak menghakimi orang lain. 


\section{b. Kelompok staf pengajar/dosen}

Serupa dengan kelompok pengelola program studi, informan dari kelompok staf pengajar juga mengemukakan karakterkarakter yang lebih cederung ke arah kemampuan untuk berhubungan dengan orang lain dan kemampuan mengarahkan diri sendiri untuk mencapai tujuan. Karakter berupa kemampuan untuk berhubungan dengan orang lain yang dimunculkan antara lain adalah kemampuan untuk kerjasama, menghargai dan menghormati orang lain, bersikap asertif dan empati, serta sosialis atau mementingkan kepentingan bersama di atas kepentingan diri sendiri. Sedangkan karakter yang berhubungan dengan kemampuan mengarahkan diri untuk mencapai tujuan yang dimunculkan dalam kelompok ini serupa dengan kelompok sebelumnya. Karakter yang dianggap perlu adalah disiplin, antusias, konsisten, idealis, dan totalitas dalam mengerjakan sesuatu.

\section{c. Kelompok mahasiswa angkatan 2005}

Sedikit berbeda dengan informan dari dua kelompok sebelumnya, informan dari kelompok mahasiswa angkatan 2005 memberi penekanan yang cukup seimbang antara karakter yang berhubungan dengan kemampuan mengatur diri dan kemampuan berhubungan dengan orang lain. Kemampuan mengatur diri yang dimunculkan antara lain adalah konsintensi, totalitas, idealis, dan tangguh dalam menjalani proses. Sedangkan kemampuan untuk berhubungan secara efektif dengan orang lain yang dimunculkan adalah kemampuan untuk kerjasama dan mengembangkan kecerdasan sosial.

\section{d. Kelompok mahasiswa angkatan 2007}

Berbeda dengan informan dari angkatan 2005, informan dari angkatan 2007 hanya memberi penekanan pada kemampuan untuk mengarahkan diri untuk mencapai tujuan maupun kemampuan mengatasi kegagalan. Beberapa karakter yang dimunculkan oleh informan dari kelompok ini adalah rajin, konsisten, optimis, percaya diri, jujur, dan tangguh ketika mengalami hambatan berupa kegagalan.

\section{e. Kelompok mahasiswa angkatan 2008 Informan dari kelompok mahasiswa} angkatan 2008 memberi penekanan pada kemampuan untuk mengatasi kegagalan. Beberapa karakter yang dimunculkan adalah kemampuan untuk berpikir positif, ikhlas, istiqomah, tangguh, tabah, introspeksi, dan resilien atau kemampuan untuk pulih setelah mengalami kegagalan. Selain itu, informan dari kelompok ini juga memunculkan karakter disiplin, tanggung jawab, teliti, idealis, tawakkal, dan konsisten. Sedangkan, karakter berupa kemampuan untuk berhubungan dengan orang lain yang dimunculkan oleh informan dari kelompok ini adalah kemampuan untuk memahami dan menghormati orang lain terutama guru atau pendidik, serta kecenderungan untuk rendah hati.

f. Kelompok mahasiswa angkatan 2009

Serupa dengan informan dari kelompok mahasiswa angkatan 2005, informan dari kelompok mahasiswa angkatan 2009 memberi penekanan yang cukup seimbang antara karakter berupa kemampuan mengatur diri sendiri maupun kemampuan berhubungan dengan orang lain. Karakter berupa kemampuan mengatur diri yang muncul dari informan dalam kelompok ini adalah teliti, idealis, dan totalitas dalam menjalani proses. Selain itu informan juga mengungkap karakter yang berhubungan dengan kemampuan mengelola kegagalan. Beberapa di antaranya adalah kemampuan untuk berpikir positif, ikhlas, dan optimis. Sedangkan karakter berupa kemampuan 
untuk berhubungan baik dengan orang lain yang muncul dari informan di kelompok ini adalah kemampuan untuk bekerja sama dengan teman, saling menghargai dan kecenderungan untuk rendah hati.

Lexmond dan Reeves (2009) menjelaskan bahwa karakter sebagai kecakapan atau kemampuan individu merupakan modalitas penting untuk meraih kesejahteraan hidupnya. Seperti yang dikemukakan oleh Aristoteles bahwa menjadi orang yang berkarakter baik berarti berhasil mengerjakan tugas mencapai kehidupan yang baik secara sempurna. Aristoteles menggambarkan tugas utama manusia adalah sesuatu yang kita cari untuk sesuatu itu sendiri - yang berarti tugas kita tidak pernah berakhir.

Lebih lanjut Lexmond dan Reeves (2009) menjelaskan tiga karakter dasar yang perlu dikembangkan untuk menyelesaikan tugas tersebut, yaitu kegigihan, regulasi diri, dan empati. Kegigihan merupakan kesetiaan, keteguhan, kelekatan yang positif individu terhadap sesuatu yang sedang dilakukan. Regulasi diri (self regulation) adalah kemampuan berupa daya lentur dalam kontrol emosi atau resiliensi yaitu kemampuan untuk bangkit kembali setelah mengalami kekecewaan, konflik, dan tekanan. Empati merupakan kemampuan menempatkan diri dan merasakan apa yang dirasakan orang lain.

Karakter dasar kegigihan dan regulasi diri dapat dihubungkan dengan kemampuan mengatur diri untuk mencapai tujuan yang telah ditetapkan. Jika karakter kegigihan menunjuk pada kemampuan mengarahkan konsentrasi dan usaha ke arah tujuan, karakter regulasi diri lebih menunjuk pada kemampuan mengelola perasaan negatif yang muncul akibat kegagalan yang dialami. Sedangkan karakter dasar yang ketiga, yaitu empati, dapat lebih dihubungkan dengan kemampuan menjalin hubungan baik dengan orang lain secara efektif.

Menurut Lexmond dan Reeves (2009), ketiga karakter itulah yang diperlukan oleh individu untuk mencapai tujuan berupa kehidupan yang lebih baik. Berdasarkan pengertian-pengertian tersebut, maka karakter-karakter yang muncul dalam temuan penelitian dari masing-masing kelompok informan dapat dijadikan karakter turunan dari karakter-karakter dasar tersebut dan dapat dikelompokkan sebagai berikut : 1. Kegigihan

Karakter-karakter temuan yang dimunculkan oleh informan dalam setiap kelompok yang dapat dijadikan karakter turunan dari karakter dasar kegigihan secara umum sama. Informan dalam kelompok pengelola program studi memunculkan karakter disiplin, tanggung jawab, konsekuen, concern, totalitas, komitmen, profesional, dan proaktif yang dapat dijadikan karakter turunan dari karakter dasar kegigihan. Dari informan dalam kelompok staf pengajar/ dosen, karakter-karakter temuan yang dapat dijadikan karakter turunan dari karakter dasar kegigihan adalah totalitas, disiplin, antusias, konsisten, dan idealis. Dari informan dalam kelompok mahasiswa angkatan 2005, karakter-karakter temuan yang dapat dijadikan karakter turunan dari karakter dasar kegigihan adalah idealis, totalitas, dan konsisten. Dari informan dalam kelompok mahasiswa angkatan 2007 diperoleh karakter rajin dan konsisten yang dapat dijadikan karakter turunan dari karakter dasar kegigihan. Informan dalam kelompok mahasiswa angakatan 2008 memunculkan karakter disiplin, tanggung jawab, teliti, idealis, tawakkal, dan konsisten sebagai karakter turunan dari karakter dasar kegigihan. Sedangkan karakter teliti, totalitas, dan idealis diperoleh dari informan dalam kelompok mahasiswa dari angkatan 2009. 


\section{Regulasi diri}

Karakter-karakter yang dapat menjadi karakter turunan dari regulasi diri hanya mendapat penekanan yang sedikit oleh informan dari kelompok pengelola prodi dan staf pengajar/dosen. Hanya karakter jujur yang dimunculkan oleh dua kelompok ini sebagai karakter turunan dari karakter dasar regulasi diri. Berbeda dengan dua kelompok tersebut, keempat kelompok mahasiswa memunculkan banyak karakter yang dapat dijadikan turunan dari karakter dasar regulasi diri. Karakter tangguh dimunculkan oleh informan dari kelompok mahasiswa angkatan 2005 dan angkatan 2007. Selain tangguh, informan dari kelompok mahasiswa angkatan 2007 juga memunculkan karakter optimis, percaya diri, dan jujur. Karakter tangguh juga dimunculkan oleh kelompok mahasiswa angkatan 2008. Selain tanggung, informan dari kelompok mahasiswa angkatan 2008 juga memunculkan karakter seperti berpikir positif, ikhlas, resilien, istiqomah, tabah, dan introspeksi. Serupa dengan angkatan 2008, informan dari angkatan 2009 juga mengemukakan karakter ikhlas dan berpikir positif, serta optimis.

\section{Empati}

Karakter-karakter yang dapat dijadikan turunan dari karakter dasar empati secara umum dimunculkan dari setiap kelompok kecuali dari kelompok mahasiswa angkatan 2005. Karakter yang dimunculkan informan dari kelompok pengelola prodi secara umum sama dengan informan dari kelompok staf pengajar / dosen, yaitu kemampuan untuk mendengarkan, memahami, menghargai, dan menghormati orang lain, bekerja sama, sopan/respek, tidak menghakimi orang lain, empati, dan sosialis atau mendahulukan kepentingan orang lain daripada kepentingan sendiri. Sedangkan dari kelompok mahasiswa, tidak banyak karakter temuan yang dapat dijadikan turunan dari karakter dasar empati. Beberapa karakter yang mundul adalah kemampuan kerjasama, memahami, menghargai, dan menghormati orang lain terutama guru atau pendidik lainnya, rendah hati, dan cerdas secara sosial.Karakter dasar beserta karakter-karakter turunannya dapat dilihat pada tabel 1.berikut ini.

Tabel 1. Karekter Dasar dan Karakter Turunan

\begin{tabular}{|c|c|c|c|c|}
\hline \multirow[t]{2}{*}{ No. } & \multirow[t]{2}{*}{ Informan } & \multicolumn{3}{|c|}{ Karakter Dasar } \\
\hline & & Kegigihan & Regulasi-diri & Empati \\
\hline 1. & E dan $R$ & $\begin{array}{l}\text { - Disiplin } \\
\text { - Tanggung jawab } \\
\text { - Konsekuen } \\
\text { - Concern } \\
\text { - Totalitas } \\
\text { - Komitmen } \\
\text { - Profesional } \\
\text { - Proaktif }\end{array}$ & • Jujur & $\begin{array}{l}\text { - Mendengarkan orang } \\
\text { lain } \\
\text { - Menghargai orang } \\
\text { lain } \\
\text { - Kerjasama } \\
\text { - Sopan } \\
\text { - Tidak menghakimi } \\
\text { - Memahami orang } \\
\text { lain } \\
\text { - Respek }\end{array}$ \\
\hline
\end{tabular}




$\begin{array}{ll}\text { 2. Dosen } & \text { - Totalitas } \\ & \text { - Disiplin } \\ & \text { - Antusias } \\ & \text { - Konsisten } \\ & \text { - Idealis }\end{array}$

3. 2005

4. $\quad 2007$

5. 2008

6. 2009
- Idealis

- Totalitas

- Konsisten

- Rajin

- Konsisten

- Disiplin

- Tanggung jawab

- Teliti

- Idealis

- Tawakkal

- Konsisten
Dari pengelompokan jawaban tersebut, dapat dilihat bahwa ada karakter turunan dari masing-masing karakter dasar yang muncul di masing-masing kelompok informan kurang lebih serupa. Setiap kelompok informan memunculkan karakter turunan dari karakter dasar kegigihan, regulasi diri, dan empati. Hanya saja penekanan dari ketiga karakter dasar tersebut berbeda pada setiap kelompok.

Pada kelompok dosen dan perwakilan dari pengurus program studi lebih menekankan pada karakter dasar kegigihan dan empati, sedangkan pada kelompok
- Kerjasama

- Menghargai orang lain

- Sosialis

- Empati

- Menghormati orang lain

- Asertif

- Cerdas sosial

- Kerjasama

- Optimis

- Percaya diri

- Tangguh

- Jujur

- Positive thinking

- Ikhlas

- Resilien

- Istiqomah

- Tangguh

- Tabah

- Katarsis

- Introspeksi

- Positif thinking

- Ikhlas

- Optimis
- Memahami orang lain

- Menghormati guru

- Rendah hati
- Rendah hati

- Bekerja sama dengan teman

- Saling menghargai

perwakilan mahasiswa dari tiap angkatan justru lebih menekankan pada karakter dasar regulasi diri dan empati. Hal ini tampak dari karakter-karakter turunan yang tergali dari setiap kelompok. Hal ini menunjukkan bahwa masing-masing kelompok memiliki penghayatan yang berbeda terhadap pengalaman baik di kelas maupun di luar kelas, sehingga memberi penekanan yang berbeda untuk karakter dasar yang diperlukan untuk mahasiswa dan lulusan Psikologi. Perbedaan ini dapat disebabkan antara lain karena penghayatan tiap kelompok terhadap pengalaman di kelas 
maupun di luar kelas.

Kelompok dosen dan perwakilan pengurus prodi melihat bahwa dari pengalaman selama ini, mahasiswa lebih membutuhkan karakter yang bersifat kegigihan atau kemampuan bertahan dengan suatu tugas yang diberikan, serta karakter empati yang bersifat merasakan kondisi orang lain. Hal ini mungkin dikarenakan pengalaman beberapa dosen yang melihat tingkah laku mahasiswa di kelas maupun di luar kelas yang kurang menunjukkan kedua hal tersebut. Padahal menurut hemat para staf pendidik, perkuliahan di Psikologi yang cukup berat serta persaingan di dunia kerja dan masyarakat mutlak memerlukan kedua karakter dasar tersebut.

Kelompok dosen dan mahasiswa sama-sama melihat karakter dasar kegigihan mutlak diperlukan, namun kelompok mahasiswa melihat karakter dasar regulasi diri lebih diperlukan daripada karakter dasar empati. Hal ini dapat menunjukkan bahwa atmosfir yang tercipta di kalangan peserta didik di prodi Psikologi cenderung bersifat persaingan atau kompetisi. Sehingga masingmasing individu cenderung menekankan kegigihan dan regulasi diri untuk mencapai tujuan diri sendiri dan cenderung kurang memandang penting karakter dasar empati. Kepentingan kolektif tidak menjadi tujuan utama di kalangan mahasiswa.

Padahal jika melihat dari sisi kepentingannya, maka ketiga karakter dasar beserta turunan-turunannya tersebut mutlak diperlukan oleh mahasiswa yang masih menjalani proses perkuliahan maupun bagi lulusan prodi Psikologi yang hendak menerapkan apa yang telah diperoleh di perkuliahan ke dalam masyarakat. Oleh karena itu, implementasi pengembangan karakter yang akan dilakukan terhadap mahasiswa harus memberi porsi yang seimbang untuk ketiga karakter dasar tersebut. Hal ini dilakukan agar tercipta lulusan Psikologi yang gigih, memiliki regulasi diri yang baik, dan mampu berempati dengan sesama sehingga mencapai keberhasilan baik dalam menyelesaikan perkuliahan maupun ketika terjun ke masyarakat.

\section{Simpulan}

Penelitian ini mengungkapkan karakter-karakter yang dibutuhkan oleh mahasiswa prodi Psikologi Fakultas Ilmu Sosial dan Humaniora Universitas Islam Negeri Yogyakarta. Ada banyak karakter yang ditemukan dalam penelitian ini. Karakter-karakter tersebut dapat dikelompokkan menjadi tiga karakter pokok, yaitu kegigihan, regulasi diri, dan empati. Ketiga karakter pokok tersebut meskipun memiliki turunan karakter-karakter yang masing-masing secara umum sama, namun penekanannya berbeda. Kelompok dosen dan pengurus prodi menekankan pada pentingnya karakter dasar kegigihan dan empati, sedangkan kelompok mahasiswa lebih menekankan pada pentingnya karakter dasar kegigihan dan regulasi diri.

\section{Daftar Pustaka}

Beland, K. (Ed.) (2003). Eleven Principle Sourcebook: How to Achieve Quality Character Education in K-12 Schools. Washington, DC: Character Education Partnership.

Kohlberg, L. (1984). The Psychology of Moral Development. San Francisco: Harper \& Row.

Lexmond, J., \& Reeves, R. (2009). Building Character. London: Mixed Sourced.

Moleong, L.J. (2006). Metodologi Penelitian Kualitatif. Bandung: Rosda Karya.

Nelson, E.E., Leibenluft, E., McClure, 
E.B., and Pine, D.S. (2005). The Social Reorientation of Adolescence: A Neuroscience Perspective on The Process and Its Relation to Psychopathology. Psychological Medicine, 35, 163-174. Retrieved February 27, 2007 from Cambridge University Press.

Nuh, M. (2011). Pendidikan Karakter Sejak Usia Dini. Sambutan Upacara Peringatan Hari Pendidikan Nasional Kementrian Pendidikan Nasional Republik Indonesia. Yogyakarta: Harian Kedaulatan Rakyat, Selasa, 3 Mei 2011, h.10.

Poerwandari, E.K. (1998). Pendekatan Kualitatif dalam Penelitian Psikologi. Jakarta: Lembaga Pengembangan Sarana Pengukuran dan Pendidikan Psikologi, Fakultas Psikologi Universitas Indonesia.

Sumargono. (2011). Laksanakan Ajaran Ki Hajar Dewantara. Suplemen Pendidikan SKH Kedaulatan Rakyat: Swara Kampus. Yogyakarta: Harian Kedaulatan Rakyat, 3 Mei 2011.
Veenstra, R., \& Kupyer, H. (2004). Effective Student and Families: The Importance of Individual Characteristics for Achievement in High School. Educational Research and Evaluation, Vol. 10, No.1, pp. 41-70.

Vezzuto, L.A. (2004). How Young People Develop Character: A Conceptual Framework with Descriptions of Promising Practices. Institute for Character Education.

Waluyo, B. (2011). Tinggi, Peran Tenaga Pendidik. Sambutan Peringatan Hari Pendidikan Nasional, Hari Kesatuan Gerak PKK ke-39, dan Bulan Bhakti Gotong Royong Masyarakat di Salatiga. Yogyakarta: Harian Kedaulatan Rakyat, Selasa 3 Mei 2011, h. 17.

Yin, R.K. (2003). Studi Kasus: Disain dan Metode (Penerjemah M. Djauzi Mudzakir). Jakarta: Raja Grafindo Persada. 